\title{
Isolate and Extract for Milk Clotting Enzymes from the leaves of Moringa Oleifera, Carica Papaya and Mangifera Indica and Use in Cheese Making: The Case of Western Hararage Region, Ethiopia
}

\author{
Abebe Getu Derso ${ }^{1, *}$, Getachew Gashaw Dagnew ${ }^{2}$ \\ ${ }^{1}$ Department of Food Science and Nutrition, Oda Bultum University, Chiro, Ethiopia \\ ${ }^{2}$ Department of Biology, Oda Bultum University, Chiro, Ethiopia \\ *Corresponding author: abebeg333@gmail.com
}

Received December 16, 2018; Revised March 18, 2019; Accepted March 24, 2019

\begin{abstract}
Milk-clotting activity was screened from leaves of Carica papaya, Mangifera indica and Moringa oleifera in order to use the leaf with the highest milk-clotting activity as a source of the enzyme. The results of the present study showed that milk-clotting activity was only detected in the leaf extracts of Carica papaya and Moringa oleifera and the leaf extract from the leaf of Mangifera indica showed no activity. Ammonium sulfate precipitation was used in this study and the results showed that the highest milk-clotting activity was obtained with $40 \%$ ammonium sulfate saturation. Maximum temperature for the crude extract of Carica papaya and Moringa olifera showed milk clotting activity at $70^{\circ} \mathrm{C}$ and $65^{\circ} \mathrm{C}$ respectively and also showed the highest clotting activity at a pH of 7.5 and 7 respectively. There was more than $80 \%$ retention of the milk-clotting activity of the crude extract of Carica papaya and Moringa olifera after $1 \mathrm{~h}$ incubation at $60^{\circ} \mathrm{C}$ and $55^{\circ} \mathrm{C}$ respectively and the result also indicated that the crude extract retained more than $80 \%$ of its activity between $\mathrm{pH} 5$ to $\mathrm{pH} 7.5$ and $\mathrm{pH} 5$ to $\mathrm{pH} 6$ respectively. Finally the crude extract of Carica papaya and Moringa oleifera has a highest enzymatic activity at a concentration of 70 and 90 grams respectively.
\end{abstract}

Keywords: activity, milk clotting enzyme, Carica papaya and Moringa oleifera

Cite This Article: Abebe Getu Derso, and Getachew Gashaw Dagnew, "Isolate and Extract for Milk Clotting Enzymes from the leaves of Moringa Oleifera, Carica Papaya and Mangifera Indica and Use in Cheese Making: The Case of Western Hararage Region, Ethiopia.” Journal of Food and Nutrition Research, vol. 7, no. 3 (2019): 244-254. doi: 10.12691/jfnr-7-3-10.

\section{Introduction}

Milk coagulation is the main step for producing cheese, and coagulating enzymes, which are preparations of proteolytic enzymes, have been used in cheese making for thousands of years, and they seem to be the oldest known application of enzymes. Historically, most enzyme preparations used for cheese have been extracts from the stomachs of ruminants, but coagulants from microbes and plants were also used at very early dates [1].

The transformation of raw milk to cheese is very important for developing countries such as Ethiopia. Milk and milk products play a very important role in feeding the rural and urban population of Ethiopia and have a high nutritional value and are daily produced, sold for cash or readily processed. Cheese-making starts with coagulation of milk, which is widely achieved by rennin, extracted from calf's abomasums before weaning. The worldwide increase in cheese production has reduced the availability of rennin, which became short in supply and expensive for local farmers. The reduced supply of rennin has led to the search for coagulant substitutes. Numbers of proteolytic enzymes from various sources have been used: bovine, porcine and chicken pepsins, fish chymotrypsins as well as proteases of fungi and transgenic microorganisms [2].

The use of these coagulants gave rise to unwanted final products, and led to ethic (been against genetically engineered foods), religious (Judaism and Islam), diet (vegetarianism) and public health problems (bird flu, bovine spongiform encephalopathy, H1N1 virus and microbial toxins) [3]. Recent publications on new proteases from vegetable origin for milk coagulation indicated that they are subject with growing interest for dairy technology $[4,5,6]$. Plant coagulants have been used in cheese-making since fifty centuries before our era. Since the renewal of interest in 1960, vegetable coagulants have been used the more in dairy technology; especially at the artisanal scale [7].

Cheese production with plant coagulants contributes significantly to the socioeconomic development of a 
locality, region and hence whole country where it is produced. Protein input is improved for those populations to whom restrictions are imposed by the use of animal and microbial coagulants. The technology led by farmers is easy and straightforward [3]. Such know-how can be interesting to farmers. Several plant preparations are known for cheese making. Species from Cynara genus are used successfully as source of milk-clotting enzymes in the Iberian Peninsula and Latin America. Tropical plants such as: Carica papaya, Ananas comocus, Ficus glabra, Calotropis procera and Lactuca sativa are also sources of milk-clotting enzymes $[8,9,10]$. The fruits and leaves of these plants have not yet been experimented as a source of milk-clotting enzymes, which can substitute rennin.

West Hararghe zone is characterized by mixed farming system where crop production is adjacent to livestock rearing. Though there is problem of adequate range land, farmers adapt to feed crop residues their livestock. In such a way milk is produced by smallholder farmers in which its quality and quantity affected by community location variation, lack of improved technology, availability of feed and water. Rural areas of West Hararghe zone are the sole sources of milk for the nearby town users of the zone where irregularity in demand and supply for fresh milk is affected. Moreover, by its product nature milk is perishable that can be consumed in shorter period. But many of the products are transported from far rural areas that vulnerable to loss in quality of the milk which tends to reduce the market price. It is observed that smallholder farmers of West Hararghe zone produces fermented milk such as cheese through traditional methods. Cheese is one of the numerous products from the processing of milk. Cheese is used as a form of preserving essential nutrients in milk and is an excellent source of nutrients such as protein, fat, minerals and vitamins. Cheese manufacture is essentially a dehydration process in which the fat and casein of milk are concentrated 6-10-fold [11]. Since long the animal rennin (or rennet) is employed in making cheese. The enzyme rennet is obtained on a commercial scale from the fourth or true stomach of the un-weaned calves which are specifically slaughtered for this purpose. The objective of the present work is to find alternative sources of milk-clotting enzymes from the Carica papaya, Mangifera indicaand Moringa oleifera found in West Hararghe zone; with the aim to select the best among them for the promotion of cheese making. This preliminary study describes the milk-clotting activity of each leave extract from each species, the efficiency of enzyme extraction from fresh and dried leave with distilled water and $5 \%$ sodium chloride as extracting medium. Besides, enzymatic activity of each leave extract was determined.

\section{Materials and Methods}

\subsection{Study Area}

The study was conducted in Chiro Woreda, West Hararghe Zone, Oromia region. The site was selected based on preliminary survey and due to the fact that these areas are highly known for the growth of Carica papaya, Mangifera indica, and Moringa oleifera, huge dependence of the people in the area those plants due to recent development of basic infrastructure; mainly roads and the proximity to market centers. The researcher has contacted with the woreda agricultural officers to identify which woreda is famous in those plants. Based on responses from the officials Chiro Woreda was identified due to its proximity and more famous in the production of Carica papaya, Mangifera indica, and Moringa oleifera. This Woreda is 325 kilometer away from Addis Ababa. It is geographically located between $34^{0} 18$ ' $43^{\prime \prime}$ to $43^{0} 0^{\prime} 4$ " E Latitude and $10^{\circ} 09^{\prime} 24^{\prime \prime}$ to $30^{\circ} 18^{\prime} 43^{\prime \prime} \mathrm{N}$ longitude.

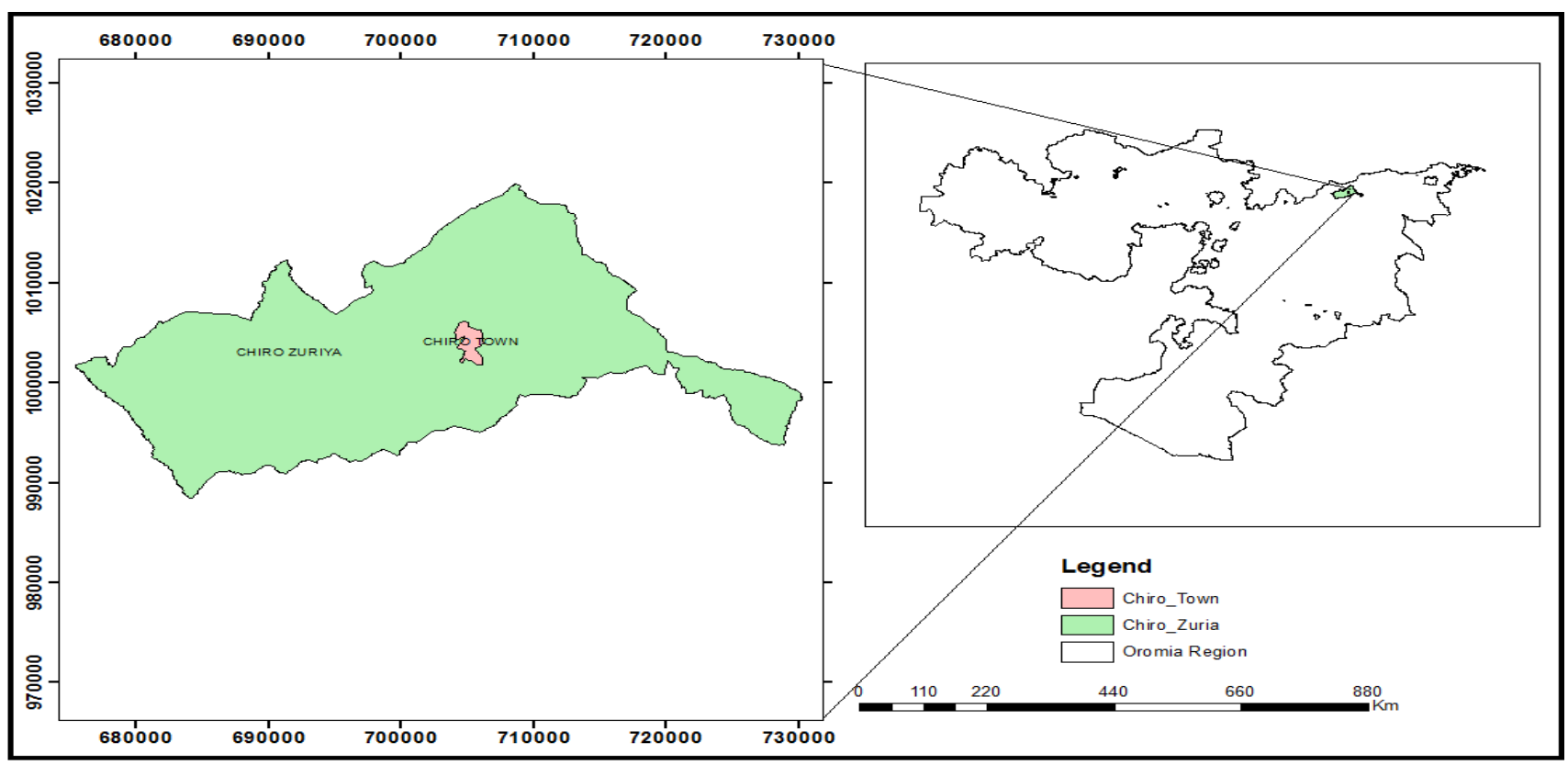

Figure 1. Map of Study Area 


\subsection{Methodology}

\subsubsection{Materials and Equipment's}

The following chemicals were used in all the analysis of the experiment: Iron Sulphate hydrated, Magnesium Sulphate hydrated, Ammonium Sulphate, Di potassium Hydrogen Sulphate, Copper Sulphate Calcium carbonate Calcium chloride, Sodium chloride, potassium chloride, Zinc Sulphate hydrated buffer, Hydroxide-Chloride buffer, Acetate buffer, Sodium hydroxide.

The equipment's which were used in the process include: sample collection units, Centrifuge, Portable $\mathrm{pH}$ meter and centrifuge.

\subsection{Experimental Procedures}

\subsubsection{Sample Collection}

The leaves of the following plants Carica papaya, Mangifera indica, and Moringa oleifera were collected early in the morning. The leaves were carefully cleaned, and then coarsely grounded using an electric grinder and kept in polyethylene bags at $4^{\circ} \mathrm{C}$ until used for enzyme extraction.

\subsubsection{Enzyme Extraction}

The crude extract enzyme of Carica papaya, Mangifera indica, and Moringa oleifera leaves were prepared using different extracting buffers as described previously (Mohamed Ahmed et al. 2009a). Briefly, duplicate samples of $10 \mathrm{~g}$ of Carica papaya, Mangifera indica,and Moringa oleifera powder was immersed in $100 \mathrm{~mL}$ of sodium acetate buffer. The extraction procedure was continued for $24 \mathrm{~h}$ at $4^{\circ} \mathrm{C}$. The extracts were filtrated through cheese cloth and centrifuged at $5000 \times$ g for 20 min. The supernatant was used for enzyme purification by ammonium sulfate fractionation method.

\subsubsection{Partial Purification of the Enzyme}

Initially, solid ammonium sulfate was slowly added with stirring to the crude extract $(600 \mathrm{~mL})$ preparations to $30 \%$ saturation. The $\mathrm{pH}$ of the enzyme/ammonium sulfate solution was maintained at $\mathrm{pH} 5.0$ by a drop wise addition of either $0.1 \mathrm{~mol} / \mathrm{L} \mathrm{H}_{2} \mathrm{SO}_{4}$ or $7 \% \mathrm{NH}_{4} \mathrm{OH}$, and the mixture was then maintained on ice for $30 \mathrm{~min}$. Thereafter, the precipitates were separated from the supernatant by centrifugation at $8000 \times \mathrm{g}$ (Centurion Scientific Co., Ltd, west Sussex, UK) for $20 \mathrm{~min}$ at $4^{\circ} \mathrm{C}$. Solid ammonium sulfate was further slowly added to the supernatant to $20-100 \%$ saturation, and the solution was preserved on ice for another $30 \mathrm{~min}$ before being centrifuged at $8000 \times \mathrm{g}$ for $20 \mathrm{~min}$ at $4^{\circ} \mathrm{C}$.

The precipitates collected was dissolved in a small volume (about $2 \mathrm{~mL}$ ) of $50 \mathrm{mmol} / \mathrm{L} \mathrm{Na}$ acetate buffer, pH 5.0, and then dialyzed overnight at $4^{\circ} \mathrm{C}$ against the same buffer $(10 \mathrm{~L})$.

The extract was then centrifuged, and the supernatants were examined for milk-clotting and protease activities. The partially purified enzyme was either directly used for enzyme characterization and cheese making or freeze-dried at $-50^{\circ} \mathrm{C}$. The latter step was repeated until the quantity of the freeze-dried partially purified enzyme reached $2 \mathrm{~g}$ and stored at $-20^{\circ} \mathrm{C}$ until used for cheese making and enzyme characterization

\subsection{Analytical Methods}

\subsubsection{Determination of Milk-clotting Activity}

Milk clotting activity was determined according to the method of Arima [12] and expressed in terms of Soxhlet units (SU). One SU is defined as the amount of enzyme which clots $1 \mathrm{ml}$ of a solution containing $0.1 \mathrm{~g}$ skim milk powder and $0.00111 \mathrm{~g}$ calcium chlorides in $40 \mathrm{~min}$ at $35^{\circ} \mathrm{C}$. In brief, $0.5 \mathrm{ml}$ of tested materials was added to a test-tube containing $5 \mathrm{ml}$ of reconstituted skim milk solution (10g dry skim milk/ 100ml, $0.01 \mathrm{M} \mathrm{CaCl}$ ) pre-incubated at $35^{\circ} \mathrm{C}$ for $5 \mathrm{~min}$. The mixture was mixed well and the clotting time $\mathrm{T}$ (sec), the time period starting from the addition of test material to the first appearance of clots of milk solution, was recorded and the clotting activity was calculated using the following formula:

$$
\mathrm{SU}=2400 \times 5 / \mathrm{Tx} 0.5 ; \mathrm{T}=\text { clotting time }(\mathrm{sec}) \text {. }
$$

The test materials include liquid solution of crude enzyme from extracts of fruit and leaves.

\subsection{Cheese Making}

Cheese was produced according to the procedure of Talib et al. (2006, 2009) with slight modifications. Briefly, $25 \mathrm{~L}$ of fresh cows' milk was heated at $72^{\circ} \mathrm{C}$ for $15 \mathrm{sec}$ and then cooled to $45^{\circ} \mathrm{C}$, and $\mathrm{CaCl}_{2}$ was added at the rate of $0.02 \%$. Then, a starter culture of lactic acid (Lactobacillus bulgaricus and Lactobacillus thermophilus) was added at the rate of $2.0 \% \mathrm{w} / \mathrm{v}$ and left for $30 \mathrm{~min}$ to develop acidity. The partially purified freeze-dried enzymes of the leaves were added to the milk at the rate of $2 \mathrm{~g} / 50 \mathrm{~L}$ of milk. The milk was mixed and left until coagulation completed.

\subsection{Characterization of Partially Purified Enzyme}

\subsubsection{Effect of Temperature on Activity of the Extract}

To study the effect of temperature on milk-clotting activity assay the reaction mixture containing $10 \%$ skim milk was incubated at a temperature range of $35-65^{\circ} \mathrm{C}$. The enzyme thermo stability was also determined by pre incubating the enzyme in the temperature range of $35-70^{\circ} \mathrm{C}$. The incubation time of samples varied from 10 to $60 \mathrm{~min}$. After incubation, the samples were submitted for determination of residual activity

\subsubsection{Effect of pH on Activity of the Extract}

To study the effect of $\mathrm{pH}$ on milk-clotting activity assay, the reaction mixture containing $10 \%$ skim milk was adjusted to different $\mathrm{pH}$ (3.5-8.5). The buffers used were: $0.1 \mathrm{M}$ citrate-phosphate ( $\mathrm{pH}$ 3.5-6.0). For $\mathrm{pH}$ stability, the enzyme will be dispersed $(1: 1)$ in the following $0.1 \mathrm{M}$ buffer solutions: $\mathrm{HCl}-\mathrm{KCl}(\mathrm{pH} 1.0-2.0)$, citrate-phosphate (pH 3.5-7.0), sodium-phosphate ( $\mathrm{pH}$ 6.0-7.5) and maintained at room temperature for $60 \mathrm{~min}$, and afterwards MCA was determined.

\subsubsection{Effect of Concentration of the Crude Extract}

To study the effect of concentration of the crude extract on milk-clotting activity assay, the reaction mixture 
containing $10 \%$ skim milk was adjusted to concentration of 1-100 mg of the crude extract, and afterwards MCA was determined.

\subsection{Experimental Design and Data Analysis}

All statistical analysis of different parameters was computed using appropriate software statistical package (EXCELL, SPSS). Enzymes assay was carried out in triplicates with analytical grade reagents and the average values and standard errors were calculated. Relationships among studied factors were presented using appropriate curves, tables and where necessary pictures.

\section{Result and Discussion}

\subsection{Screening of Milk-clotting Enzyme from Leaves of Carica Papaya, Mangifera Indica and Moringa Oleifera}

Milk-clotting activity was screened from leaves of Carica papaya, Mangifera indica and Moringa oleifera in order to use the leaf with the highest milk-clotting activity as a source of the enzyme. The results of the present study showed that milk-clotting activity was only detected in the leaf extracts of Carica papaya and Moringa oleifera and the leaf extract from the leaf of Mangifera indica showed no activity. Carica papaya and Moringa oleifera leaf extract used for coagulation or clotting of milk for cheese preparation throughout this study and milk clotting activity of the extracted leaves presented in Table 1 .

Similar to our findings, many previous works had been reported on the isolation of milk-clotting enzymes for the leaves and seeds of numerous plants [5,13,14,15,16]. However, various milk clotting enzymes has also been extracted from other parts of the plants $[16,17]$.

\subsection{Effect of Different Extracting Solution on the Milk-clotting Activity}

In order to obtain the highest milk-clotting activity from the leaves of Carica papaya and Moringa oleifera samples various extracting solution were tested (Figure 2). The results showed that of Carica papaya and Moringa oleifera leaf extracted with $5 \% \mathrm{NaCl}$ in sodium acetate buffer, pH 5.0 had higher milk-clotting activity compared to that extracted with the other extracting solution (Figure 2). Therefore, $5 \% \mathrm{NaCl}$ in sodium acetate buffer, $\mathrm{pH}$ 5.0, was used as an extracting buffer throughout the study.

This result is in a good agreement with the observation of Yousif [19] and Mohamed Ahmed [14,15] who stated that water extract of Solanum dubium berries and seeds had less milk clotting activity compared to that extracted with $5 \% \mathrm{NaCl}$ in acetate buffer. Moreover, Guiama [18] obtained the maximum milk-clotting activity by soaking dried berries of nine Solanum species in $5 \% \mathrm{NaCl}$ solution.

Table 1. Extracting for milk clotting activity from the leaves of Carica papaya, Mangifera indica and Moringa oleifera in different extracting solutions

\begin{tabular}{lcccc}
\hline Leaves of plants & Distilled Water (DW) & 5\% NaCl in DW & Sodium acetate buffer & 5\% NaCl in Sodium acetate buffer \\
\hline Carica papaya & 19.35 & 34.16 & 82 & 195 \\
Moringa oleifera & 16.18 & 30.12 & 68.9 & 135 \\
Mangifera indica & ND & ND & ND & ND \\
\hline
\end{tabular}

Results are average of triplicate samples. nd: not detected. MCA in Su/ml.

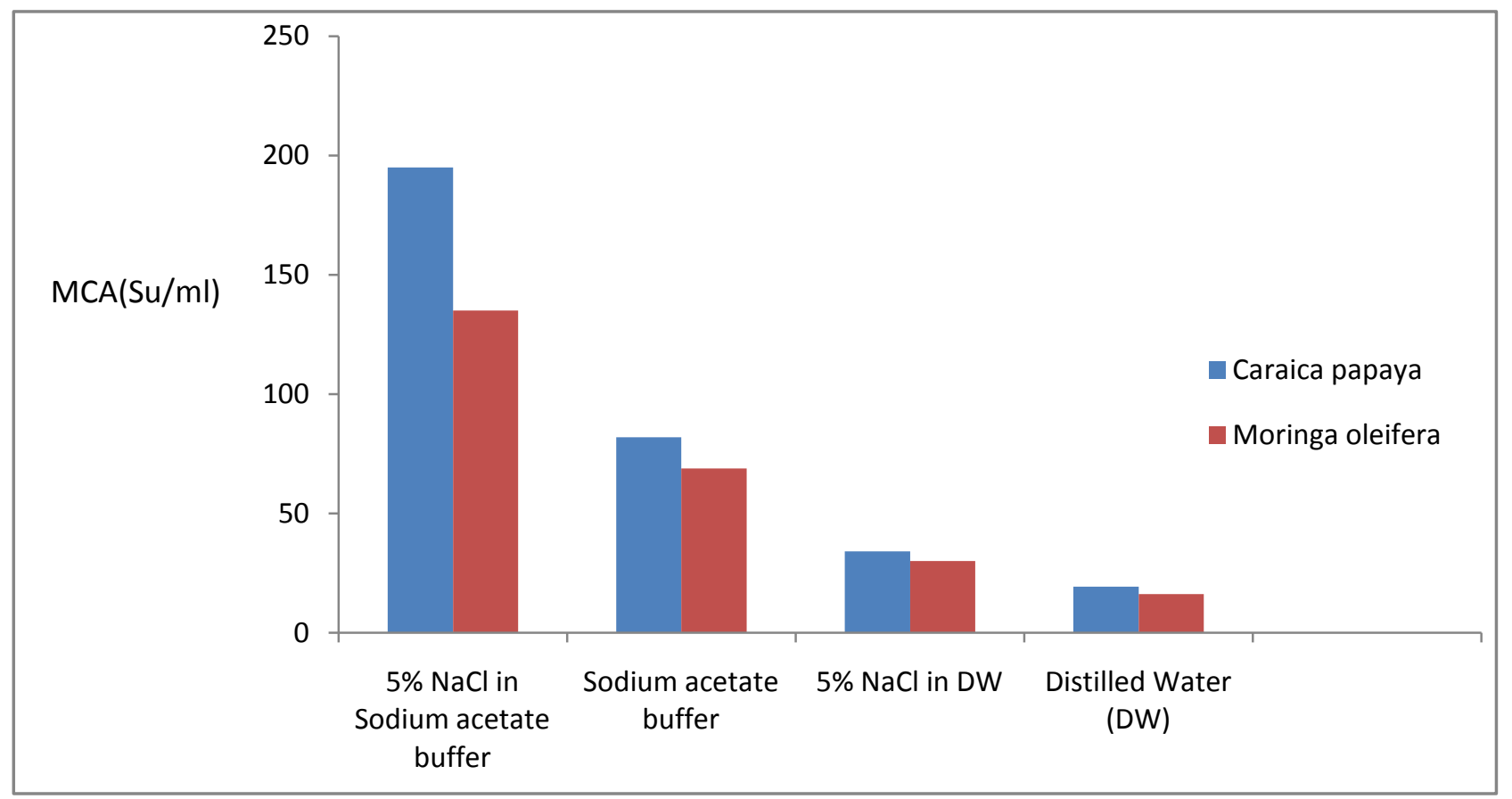

Figure 2. Ability of different extracting solutions to extract milk-clotting enzyme from the leaves of Carica papaya and Moringa oleifera 


\subsection{Partial Purification of the Enzyme}

Ammonium sulfate precipitation was used in this study, a single purification step of milk-clotting enzymes from the leaves of Carica papaya and Moringa oleifera. The crude extract was precipitated with $0-100 \%$ ammonium sulfate with $20 \%$ intervals as described in Material and Methods.

The results showed that the highest milk-clotting activity was obtained with $40 \%$ ammonium sulfate saturation, which was 5 times higher compared to that of the crude extract. With increasing the ammonium sulfate concentration the milk clotting activity was gradually decreased until completely disappeared above $100 \%$ saturation (Figure 3). Accordingly $40 \%$ ammonium sulfate saturation was selected for potential purification of the milk clotting enzyme for the leaves of Carica papaya and Moringa oleifera. This result disagree to those of Nestor [16] who reported that $20 \%$ ammonium sulfate gave the highest milk-clotting activity of Solanum Elaeagnifolium seeds extract. The results obtained in the current study indicated that the degree of saturation of ammonium sulfate greatly affected the enzyme activity, yield and as well as the enzyme purity. This procedure causes the enzyme to concentrate a workable volume that could efficiently be used for milk coagulation in cheese making industry. Overall, a one-step and cheap purification procedure has been developed to partially purify milk-clotting enzyme from Carica papaya and Moringa oleifera leaves. Such an economic purification procedure combined with the easy availability of the plant leaves make large scale preparation of the enzyme is possible, allowing a wide study of its various aspects and hence probable applications.

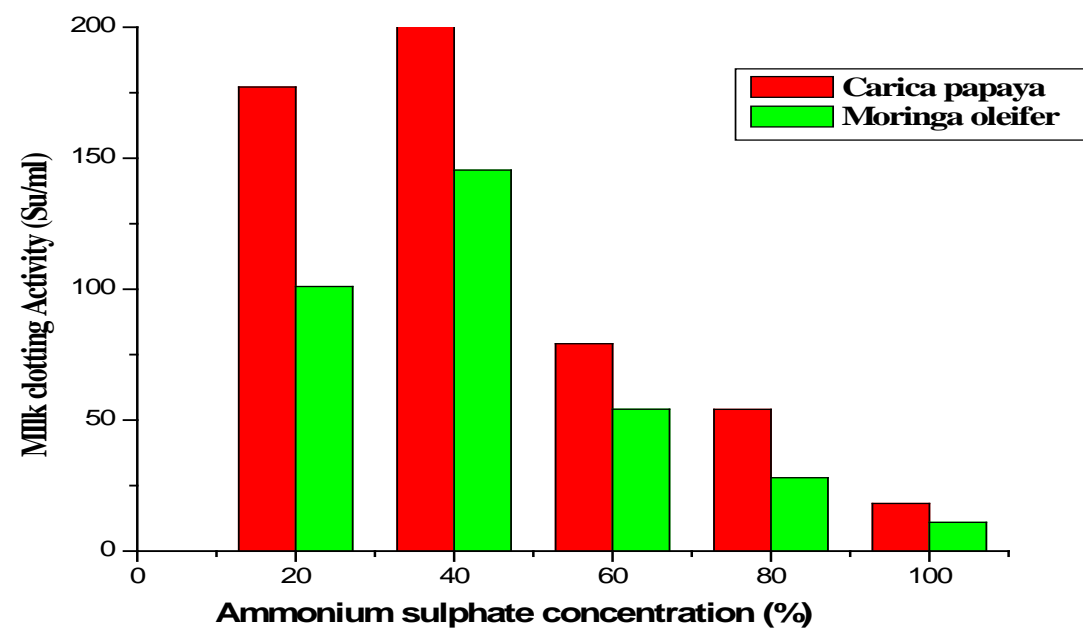

Figure 3. Ammonium sulfate fractionation of a milk-clotting enzyme from the leaves of Carica papaya and Moringa oleifera

\subsection{Preparation of Cheese from Cow Milk Using the Enzyme}

Picture A and B below has shown cheese curd produced by the partially purified milk clotting enzyme from the leaves of Moringa oleifera and Carica papaya respectively.

Picture A Making of cheese from leaves of Carica papaya

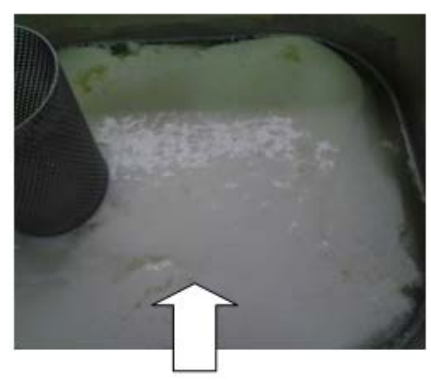

After addition of the extract

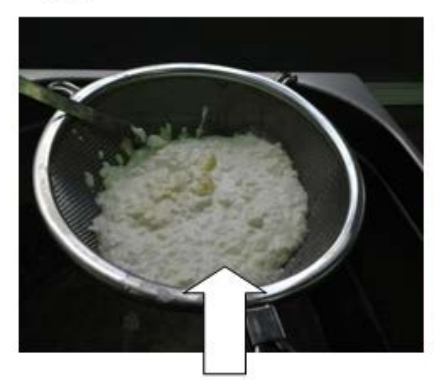

Cheese

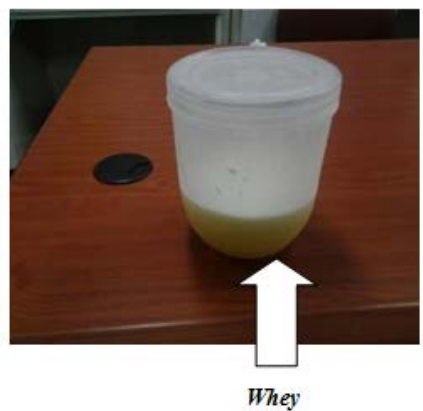

Picture B Making of cheese from leaves of Moringa oleifera

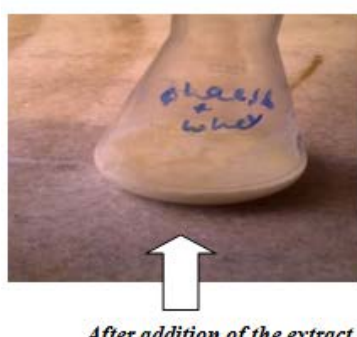

After addition of the extract
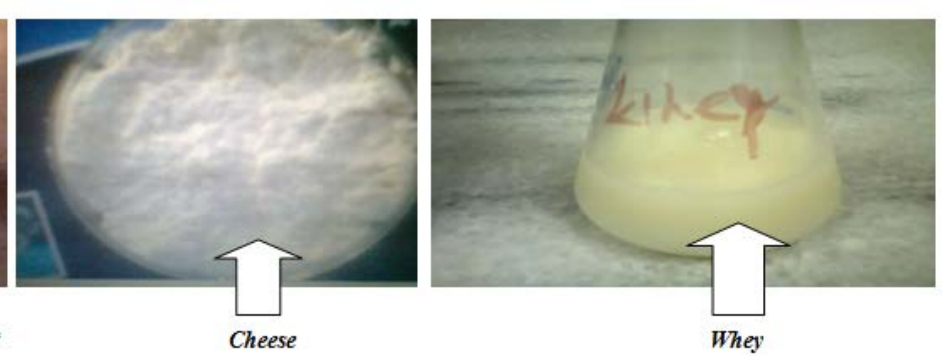


\subsection{Characterization of the Crude Enzyme}

\subsubsection{Effect of Temperature on the Enzyme Activity and Stability}

The temperature profile of the milk-clotting enzyme from plant extracts depends on several factors such as the plant source, tissue, concentration and type of protease [20]. The milk-clotting activities of the partially purified enzymes were examined using skim milk as a substrate at different temperatures ranging from 30 to $90^{\circ} \mathrm{C}$ for $30 \mathrm{~min}$. Optimum temperature range were between 30 to $90^{\circ} \mathrm{C}$ for both leaves of Carica papaya and Moringa olifera and with the maximum activity at $70^{\circ} \mathrm{C}$ and $65^{\circ} \mathrm{C}$ respectively.

The results (Figure 4) showed that the enzyme activity of Carica Papaya increased as the (reaction) temperature increased from 30 to $70^{\circ} \mathrm{C}$. The activity at $70^{\circ} \mathrm{C}$ was 7 -fold higher than that of the activity at $30^{\circ} \mathrm{C}$. The activity sharply decreased as the temperature of the reaction raised over $80^{\circ} \mathrm{C}$. However, at $80^{\circ} \mathrm{C}$ the milk-clotting activity of the enzyme was still higher compared to that at temperatures below $45^{\circ} \mathrm{C}$.
The results (Figure 5) showed that the enzyme activity of Moringa olifera increased as the (reaction) temperature increased from 30 to $65^{\circ} \mathrm{C}$. The activity at $65^{\circ} \mathrm{C}$ was 5 -fold higher than that of the activity at $30^{\circ} \mathrm{C}$. The activity sharply decreased as the temperature of the reaction raised over $75^{\circ} \mathrm{C}$. However, at $80^{\circ} \mathrm{C}$ the milk-clotting activity of the enzyme was still higher compared to that at temperatures below $35^{\circ} \mathrm{C}$. The effect of temperature on the catalytic activity of partially purified milk clotting enzymes of Carica papaya and Moringa olifera leaves exhibited a typical activity-temperature relationship of enzymes. The increase of the milk-clotting activity at higher temperature could be attributed to the protein aggregation and molecular rearrangement in the protein structure [21]. Different enzymes have different optimum temperatures; mainly depending on the enzyme structure. The conformational changes in the protein structure under high temperature could make it vulnerable to proteolysis because, protein unfolding can expose new cleavage sites to enzymatic hydrolysis. In agreement with our findings, high optimal temperature $\left(70^{\circ} \mathrm{C}\right)$ of milk-clotting enzymes from various plants has been reported [14,15,20].

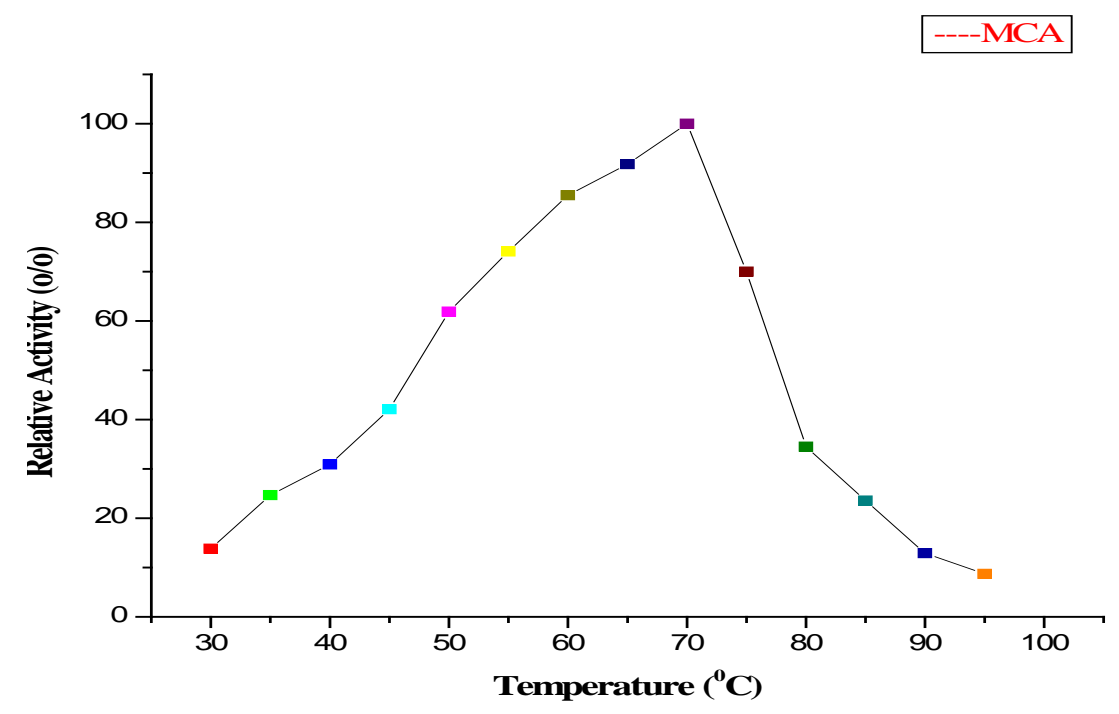

Figure 4. Optimal temperature of milk clotting enzyme from leaves of Carica papaya

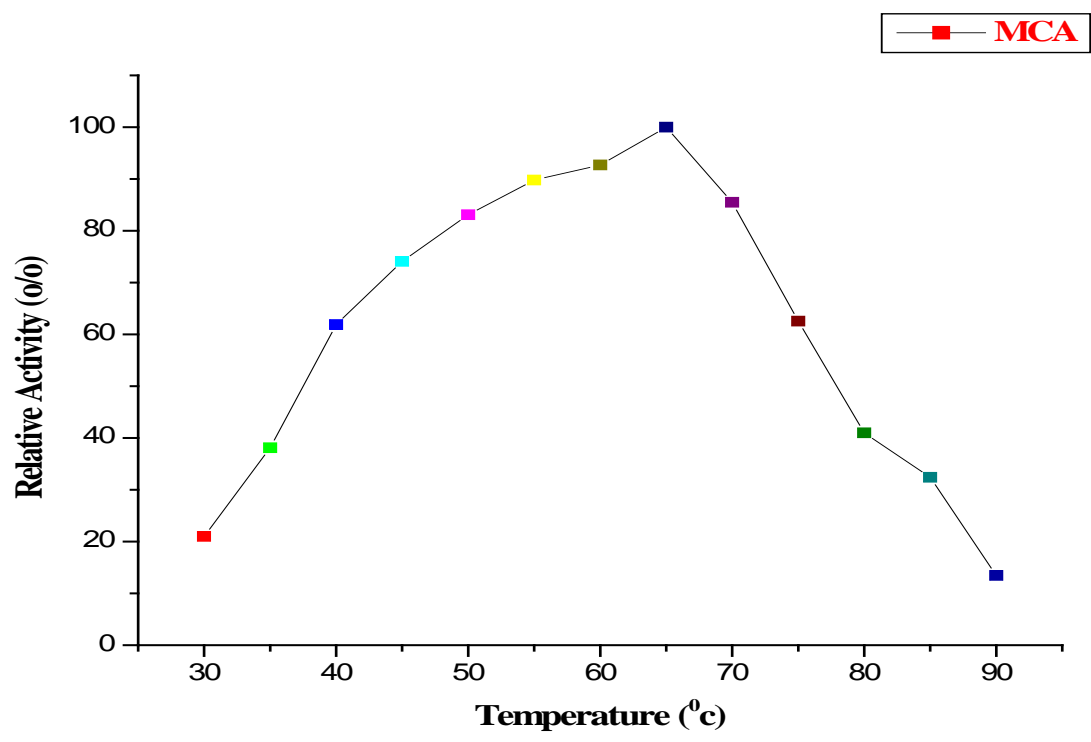

Figure 5. Optimal temperature of milk clotting enzyme from leaves of Moringa olifera 
Thermo-stability of the partially purified enzymes was examined by measuring the residual activity after incubating the enzymes at different temperatures. Since the enzyme had a high optimum temperature, its stability at temperature between 20 to $75{ }^{\circ} \mathrm{C}$ was studied.

The results from leaves of Carica Papaya (Figure 6), there were more than $80 \%$ retention of the milk-clotting activity of the enzyme from after $1 \mathrm{~h}$ incubation at $60{ }^{\circ} \mathrm{C}$ and also there was $70 \%$ retention of the milk-clotting activity of the enzyme after $1 \mathrm{~h}$ and 30 minutes incubation at $60^{\circ} \mathrm{C}$. There was more than $60 \%$ retention of the milk-clotting activity of the enzyme after $2 \mathrm{~h}$ incubation at $60^{\circ} \mathrm{C}$. However, the residual activity was quickly diminished when the enzyme was incubated for $1 \mathrm{~h}$ at $70^{\circ} \mathrm{C}$ or higher temperatures.

The results from leaves of Moringa olifera (Figure 7), there were more than $80 \%$ retention of the milk-clotting activity of the enzyme from after $1 \mathrm{~h}$ incubation at $55^{\circ} \mathrm{C}$ and also there was $70 \%$ retention of the milk-clotting activity of the enzyme after $1 \mathrm{~h}$ and 30 minutes incubation at $55{ }^{\circ} \mathrm{C}$. There was more than $50 \%$ retention of the milk-clotting activity of the enzyme after $2 \mathrm{~h}$ incubation at $60^{\circ} \mathrm{C}$. However, the residual activity was quickly diminished when the enzyme was incubated for $1 \mathrm{~h}$ at $65^{\circ} \mathrm{C}$ or higher temperatures.

With regards to the stability of the partially purified enzymes from both Carica Papaya and Moringa olifera leaves at high temperature, it behaved like milk-clotting enzymes extracted from other vegetable and microbial sources. Thermal stability in the range of $30-60^{\circ} \mathrm{C}$ for milk clotting enzymes from different plant sources has been reported [16,17]. However, the partially purified milk-clotting enzymes in the current study were characterized by their high thermal resistance as compared to calf rennet, since calf rennet reached its maximum activity at $45^{\circ} \mathrm{C}$, followed by a sharp decline when the temperature exceeded $50^{\circ} \mathrm{C}$ [22].

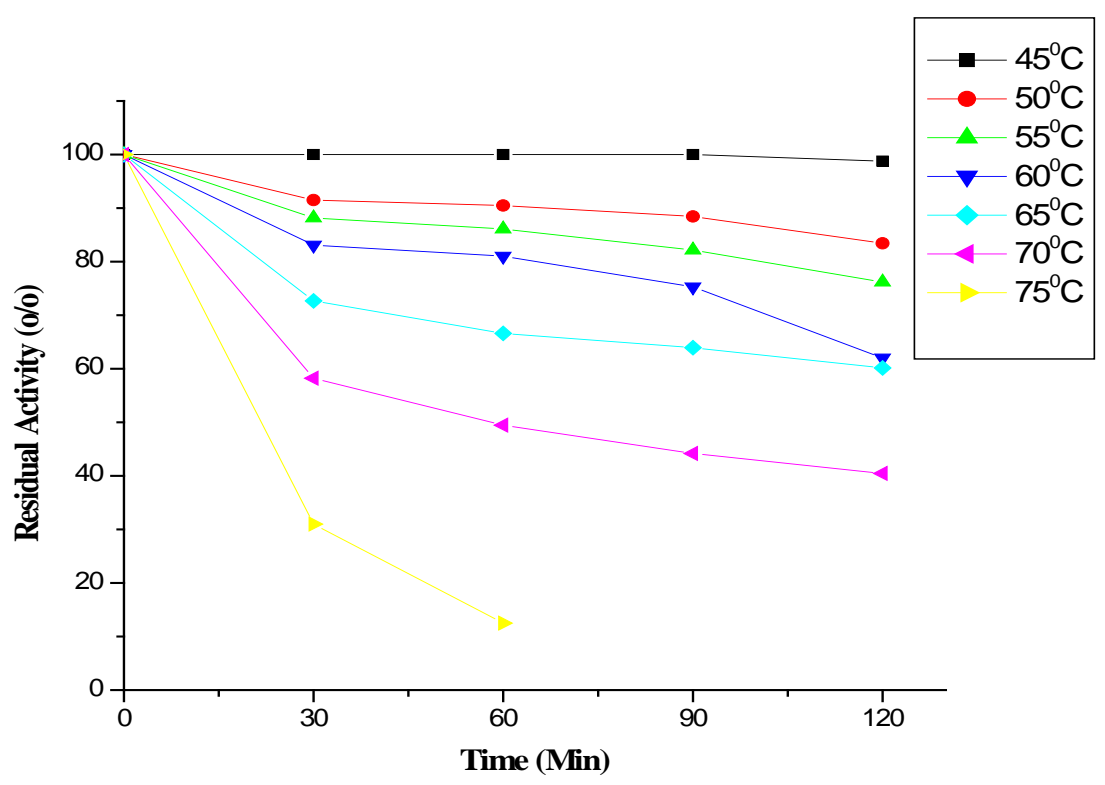

Figure 6. Thermal Stability of milk clotting enzyme from leaves of Carica Papaya

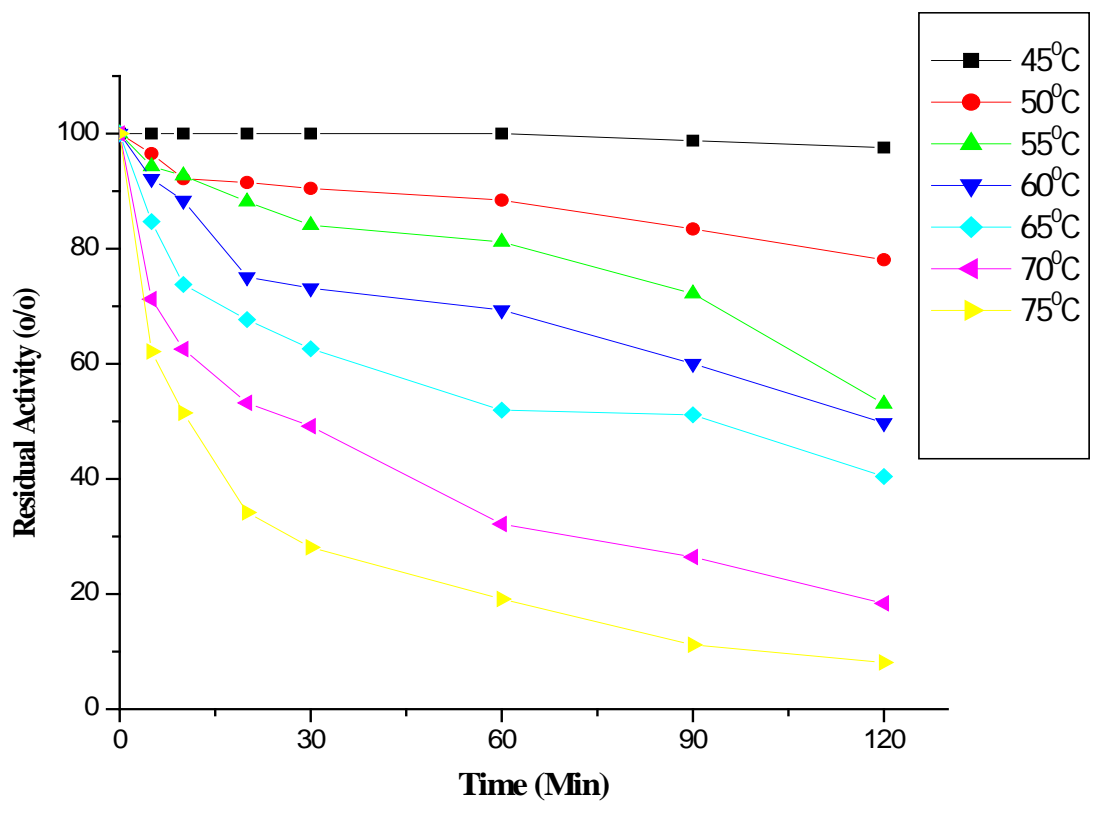

Figure 7. Thermal Stability of milk clotting enzyme from leaves of Moringa olifera 


\subsubsection{Effect of $\mathbf{p H}$ on Enzyme Activity and Stability}

Results (Figure 8) showed from leaves of Carica Papaya at different $\mathrm{pH}$ values were tested, the enzyme showed the highest protease activity at a $\mathrm{pH}$ of 7.5 and the lowest activity at a $\mathrm{pH}$ of 3 . This higher activity at alkaline $\mathrm{pH}$ suggests that the enzyme belongs to a group of proteases that are often used commercially [23]. Similar results were observed for the protease in the latex of Streblus asper, which had an optimum $\mathrm{pH}$ of 9.0, keeping it in the alkaline range [24]. The optimum $\mathrm{pH}$ of calf rennet about 6-6.3 as reported by Okigbo et al, 1985.

Results (Figure 9) showed from leaves of Moringa olifera at different $\mathrm{pH}$ values were tested, the enzyme showed the highest protease activity at a $\mathrm{pH}$ of 7 and the lowest activity at a $\mathrm{pH}$ of 3 . Similar results were observed for a protease from Jacaratia corumbensis O. Kuntze showed greater activity in a nearly neutral $\mathrm{pH}$ range- $\mathrm{pH}$ 6.5 for the crude extract of the enzyme and $\mathrm{pH} 7.0$ for the purified enzyme (Duarte et al., 2009). However, a protease from Ficus racemosa showed higher activity at an acidic $\mathrm{pH}$, with $80 \%$ of its activity occurring at a $\mathrm{pH}$ of 4.0 [25].
According to Demir [26], high pH enzymes are advantageous in food production because at lower milk $\mathrm{pH}$, it formed bad and non-firmed clots therefore, and their results were excluded. Coagulants should not be sensitive to variations in the $\mathrm{pH}$ of milk because this sensitivity can decrease the yield of cheese or cause defective cheese formation owing to clots too soft for cutting [27].

The stability of the purified enzyme from Carica Papaya at different $\mathrm{pH}$ values was shown in Figure 10. $\mathrm{pH}$ has an effects on the activity of MCE produced by Carica Papaya, held for $60 \mathrm{~min}$ and at different $\mathrm{pH}$ levels ( $\mathrm{pH} 5-10)$, as shown in Figure 10. The results indicated that the crude enzyme retained more than $80 \%$ of its activity between $\mathrm{pH} 5$ and $\mathrm{pH} 7.5$ and more than $70 \%$ of its activity at $\mathrm{pH} 6.5$ for more than $120 \mathrm{~min}$. According to Demir [26], pH stable enzymes are advantageous in food production. Papain and bromelain are traditional plant proteases reported to be stable between $\mathrm{pH} 5.0$ and 9.0 [28]. Coagulants should not be sensitive to variations in the $\mathrm{pH}$ of milk because this sensitivity can decrease the yield of cheese or cause defective cheese formation owing to clots too soft for cutting [27].

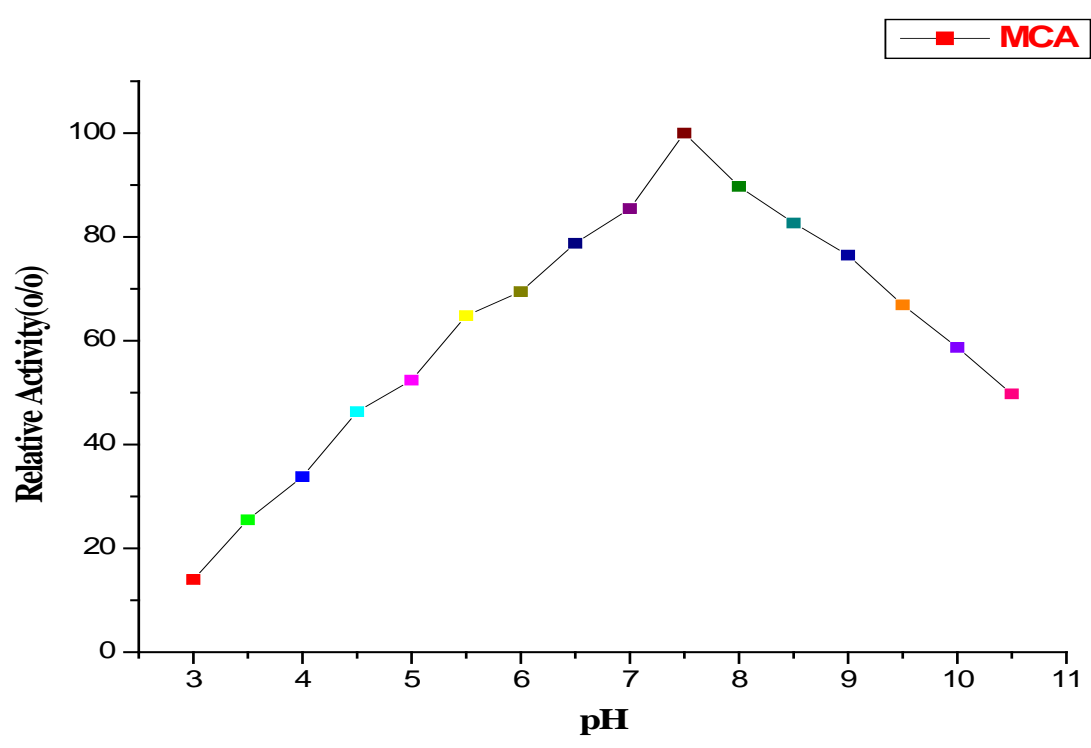

Figure 8. Optimal pH for milk clotting enzyme from leaves of Carica Papaya

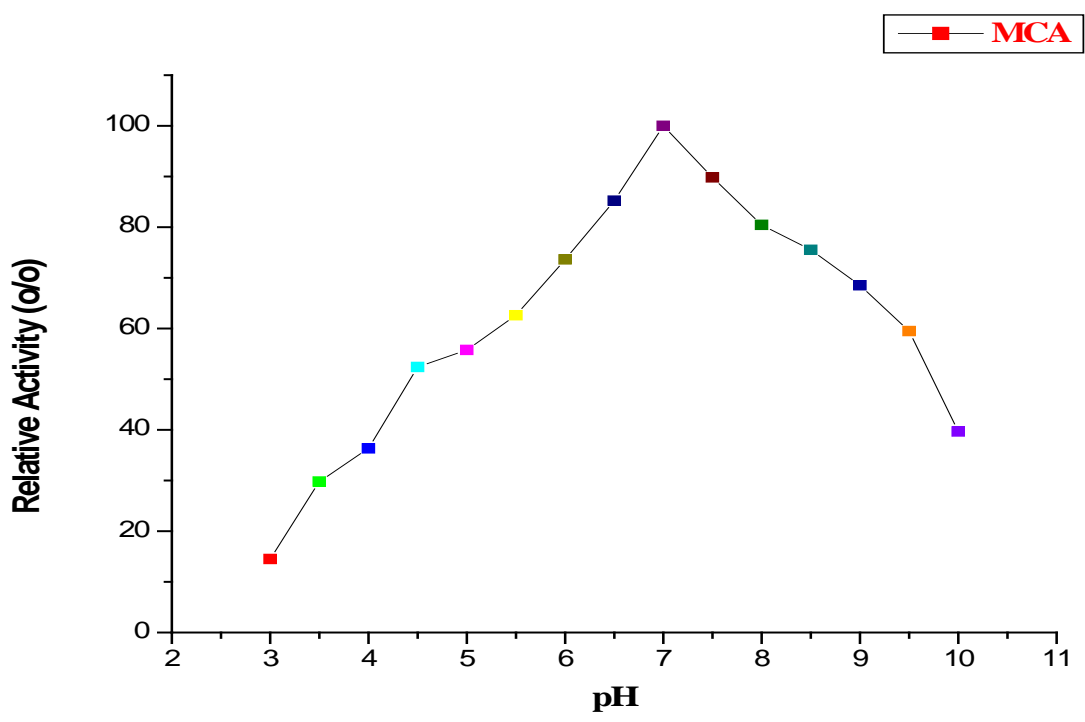

Figure 9. Optimal pH for milk clotting enzyme from leaves of Moringa 
The stability of the purified enzyme from Moringa olifera at different $\mathrm{pH}$ values was shown in Figure 11. $\mathrm{pH}$ has an effect on the activity of MCE produced from Moringa olifera, held for $60 \mathrm{~min}$ and at different $\mathrm{pH}$ levels ( $\mathrm{pH}$ 5-9), as shown in Figure 11. The results indicated that the crude enzyme retained more than $80 \%$ of its activity between $\mathrm{pH} 5$ and $\mathrm{pH} 6.5$ and more than $70 \%$ of its activity at $\mathrm{pH} 6$ for more than $120 \mathrm{~min}$.

\subsubsection{Effect of Concentration on the Activity of the Crude Extract}

The effect of concentration of the crude extract on milk clotting activity was checked between 1-100 grams of the crude extracts of Carica Papaya and Moringa oleifera as shown below in Figure 12 and Figure 13 respectively. The isolated protein fraction has a highest enzymatic activity at a concentration of 70 and $90 \mathrm{mg}$ respectively, of the crude extracts of Carica Papaya and Moringa oleifera leaves.

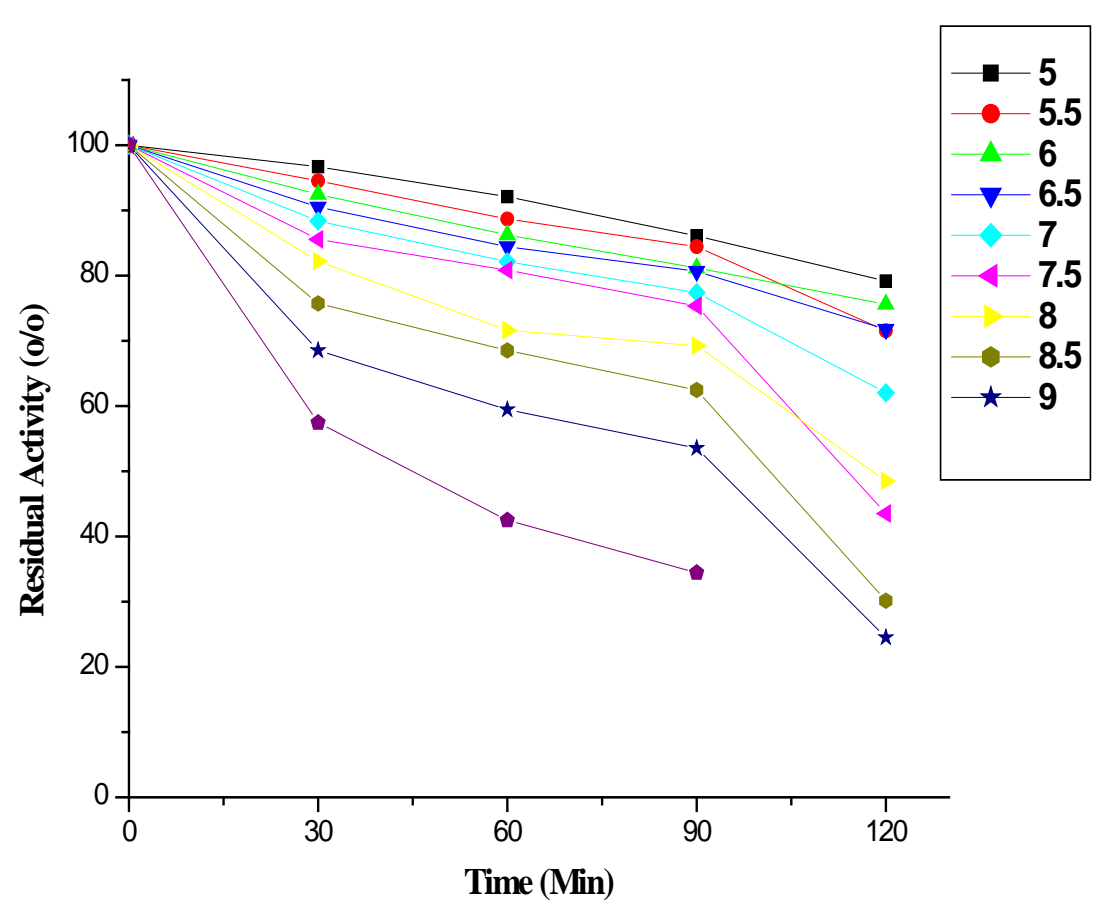

Figure 10. PH stability of milk clotting enzyme from leaves of Carica Papaya

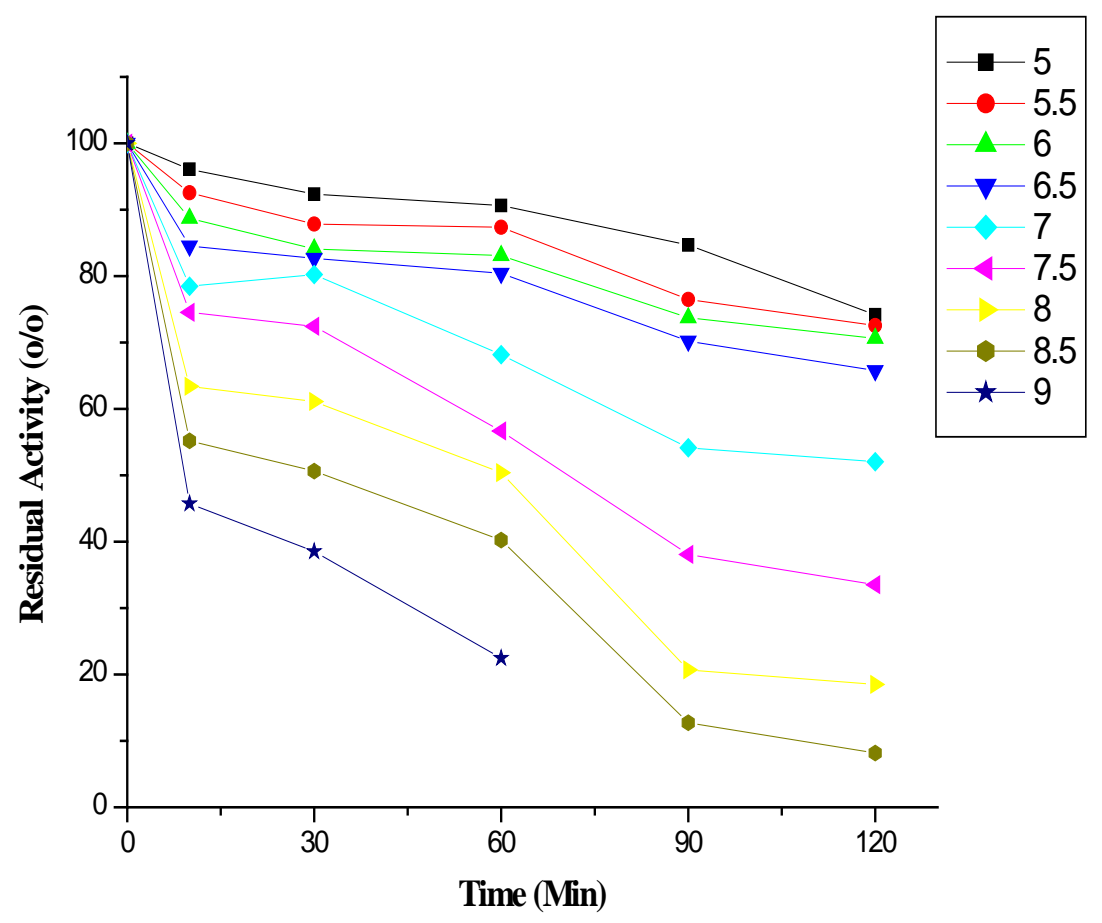

Figure 11. PH stability of milk clotting enzyme from leaves of Moringa oleifera 


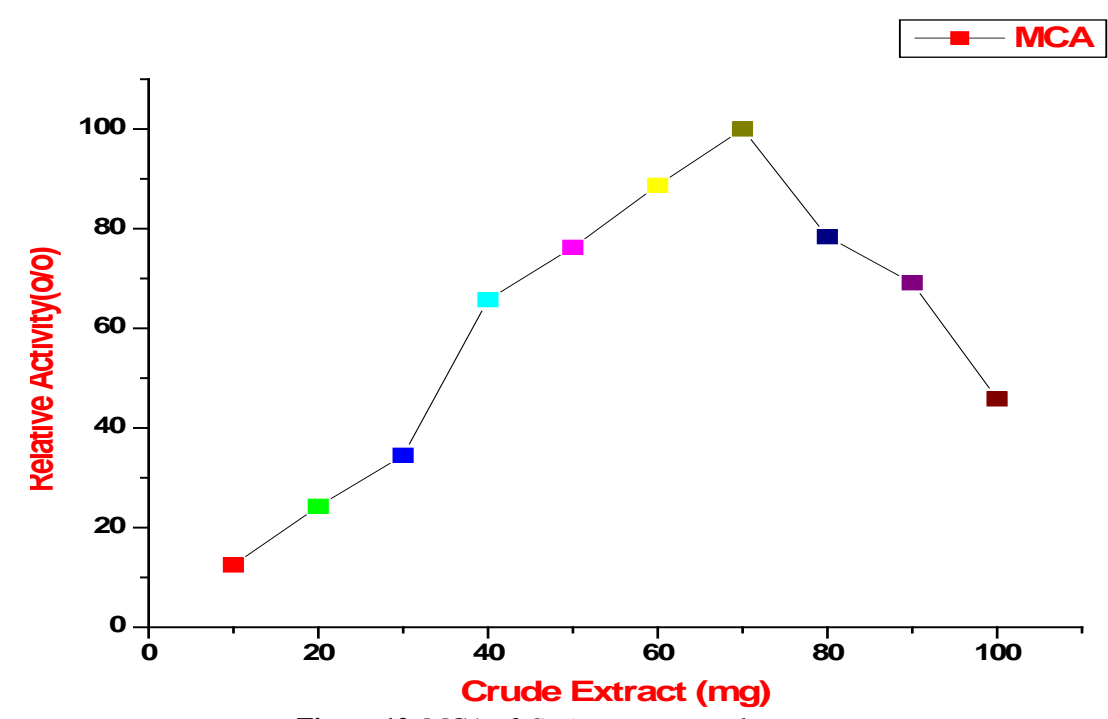

Figure 12. MCA of Carica papaya crude extract

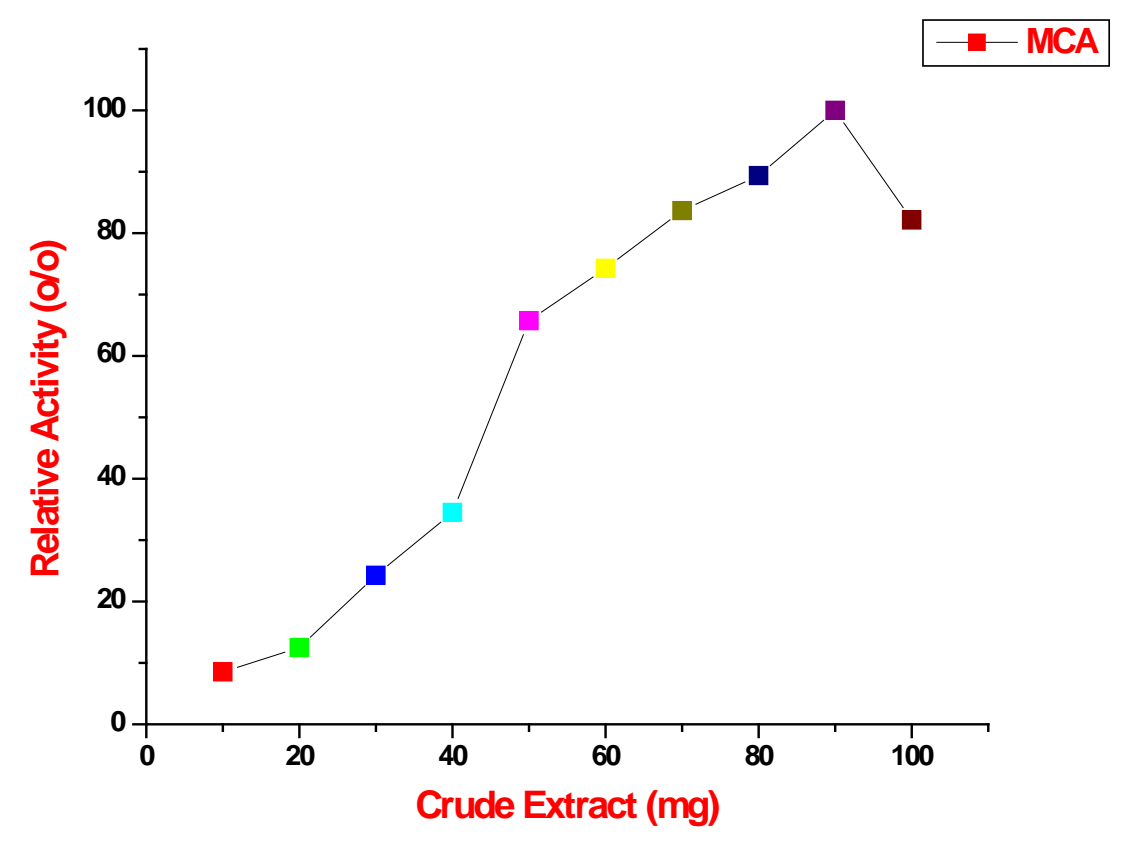

Figure 13. MCA of Moringa oleifera crude extract

\section{Conclusion}

This study could prove to the commercial production of milk clotting enzyme leaves of Carica papaya and Moringa oleifera. We develop a simple purification procedure for the production of substantial amounts of active milk-clotting enzymes from leaves of Carica papaya and Moringa oleifera as a cheap milk-clotting preparation for cheese making. In addition, the partially purified enzyme demonstrated great milk-coagulation and curd formation ability indicating its potentiality in cheese making as rennet substitute.

This paper describes the characterization and partial purification of the enzyme using ammonium sulphate. As a result milk-clotting activity increased with increasing incubation temperature and reached its maximum activity at $70^{\circ} \mathrm{C}$ and $65^{\circ} \mathrm{C}$ for leave of Carica papaya and Moringa oleifera respectively, while the activity also reached its maximum at $\mathrm{pH} 7.5$ and 7 respectively, it had showed excellent $\mathrm{pH}$ and thermal stability. Moreover, the high stability of the purified enzyme under various conditions, in accordance with the availability of raw materials, in addition to its high milk-clotting ability, could therefore pave the way for its use in the cheese industry.

\section{Recommendations}

- Extract the crude enzymes for large-scale production for industrially purpose and try it with trace amounts (milliliters);

- Experiment with other plants to make effective choice to replace animal rennet coagulant by a cheap plant in traditional cheese making in rural areas.

- Further on purification procedures to increase the activity of enzymes at lower concentration

- Further studies should be conducted on the texture, taste, chewiness, gumminess and color of the produce cheese 
- Study should be made on toxicological analysis of the produced cheese

- Study on shelf life estimation of the extract using different packaging materials.

- Study on the assessment of the MCA and proteolytic activity of extract enzyme of different species grown in Ethiopia at different maturation stages.

- Research should also be done on the evaluation of the suitability of the extract enzyme for cheese making from different milk sources such as cow, ewe, goat milk and soy milk

\section{Acknowledgements}

The success of this research would not have been possible without the financial support from Oda Bultum University, which is gratefully acknowledged. Moreover the authors would like to thank the zonal agricultural and health bureau office for providing the necessary resource and information to conduct the study

\section{References}

[1] Jacob, M., Jaros, D. \& Rohm, H. 2011. Recent advances in milk clotting enzymes. International journal of dairy technology, 64, 14-33.

[2] Lopez A, Teixeira G, Liberato MC, Pais M S and Clemente A (1998) New vegetal sources for milk clotting enzymes. Journal of Molecular Catalysis B: Enzymatic, 83-181.

[3] Roseiro LB, Barbosa M, Ames JM, Wilbey RA (2003). Cheese making with vegetable coagulants-the use of Cynara L. for the production of ovine milk cheeses. Int. J. Dairy Technol. 56(2): 76-85.

[4] Low YH, Agboola S, Zhao J, Lim MY (2006) Clotting and proteolytic properties of plant coagulants in regular and ultrafiltered bovine skim milk. Int Dairy J 16: 335-343.

[5] Egito AS, Girardet JM, Laguna LE, Poirson C, Mollé D, Miclo L, Humbert G, Gaillard JL. (2007). Milkclotting activity of enzyme extracts from sunflower and albizia seeds and specific hydrolysis of bovine $\kappa$-casein. Int Dairy J 17: 816-825.

[6] Duarte, A.R., Duarte, D.M.R., Moreira, K.A., Cavalcanti, M.T.H., Lima-Filho, J.L.D. and Porto, A.L F. (2009): Jacaratiacorumbensis O. Kuntze a new vegetable source for milk-clotting enzymes. Brazilian Archives of Biology and Technology, 52(1): 1-9.

[7] Silva SV, Malcata FX. (2005). Studies pertaining to coagulant and proteolytic activities of plant proteases from Cynara cardunculus. Food Chem 89:19-26.

[8] Uchikoba T, Kaneda M. (1996). Milk-clotting activity of cucumisin, a plant serine protease from melon fruit. Appl Biochem Biotechnol 56: 325-330.

[9] Asakura T, Watanabe H, Keiko A, Soichi A. (1997). Oryzasin as an aspartic proteinase occurring in rice seeds: purification, characterization, and application to milk-clotting. J Agric Food Chem 45: 1070-1075.

[10] Lo Piero AR, Puglisi I, Petrone G (2002) Characterization of "lettucine", a serine-like protease from Lactuca sativa leave, as a novel enzyme for milk clotting. J Agric Food Chem 50:2439-2443.
[11] Omotosho, O.E., Oboh, G. and Iweala, E.E.J. (2011), "Comparative effects of local coagulants on the nutritive value, in vitro digestibility and sensory properties of 'wara' cheese", International Journal of Dairy Science, Vol. 6 No.1, pp. 58-65.

[12] Arima.K, J. Yu, S. Iwasaki. (2007), Milk-clotting enzyme from Mucor pusillus var. Lindt, Methods in Enzymology 19; 446-459.

[13] Elmazar M. M. E., El-Sayed S. T. \& Al-Azzouny R. A. 2012. Screening Some Local Egyptian Seeds Extract for Milk-Clotting Activity and Physicochemical Characterization of Brassica Napus Seed Extract. Journal of Agriculture and Food Technology, 2(2), 28-34.

[14] Mohamed Ahmed, I. A., Morishima, I., Babiker, E. E. \& Mori, N. 2009a. Characterization of partially purified milk-clotting enzyme from Solanum dubium Fresen seeds. Food Chemistry, 116 (2), 395-400.

[15] Mohamed Ahmed, I. A., Morishima, I., Babiker, E. E. \& Mori, N. 2009b. Dubiumin, a chymotrypsin-like serine protease from the seeds of Solanum dubium Fresen. Phytochemistry, 70 (4), 483-491.

[16] Nestor, G.-M., Rubi, C.-G. D. \& Hector, J.-C. 2012. Exploring the MilkClotting Properties of a Plant Coagulant from the Berries of S elaeagnifolium var. Cavanilles. Journal of Food Science, 71(1), C89-C94.

[17] Anusha, R., SingH, M. K. \& Bindhu O.S. 2014. Characterization of potential milk coagulants from Calotropis gigantean plant parts and their hydrolytic pattern of bovine casein. European Food Research and Technology, 238, 997-1006.

[18] Guiama V. D., Libouga D. G., Ngah E. \& Mbofung C. M. 2010. Milkclotting activity of berries extracts from nine Solanum plants. African Journal of Biotechnology, 9(25), 3911-3918.

[19] Yousif, B. H., Mcmahon, J. D. \& Shammet, M. K., 1996. Milkclotting Enzyme from Solanum dobium Plant. International Dairy Journal, 6, 637-644.

[20] Mazorra-Manzano, M. A., Perea-Gutiérrez, T. C., Lugosánchez, M. E., Ramirez-Suarez, J. C., Torres-Llanez, M. J., GonzálezCórdova, A. F. \& Vallejo-Cordoba, B. 2013. Comparison of the milk-clotting properties of three plant extracts. Food Chemistry, 141, 1902-1907.

[21] Najera, A. I., De renobales, M. \& Barron, L. J. R. 2003. Effects of $\mathrm{pH}$, temperature, $\mathrm{CaCl} 2$ and enzyme concentrations on the rennetclotting properties of milk: a multifactorial study. Food Chemistry, 80, 345-352.

[22] Shehata, A.E., Fayet, E. A., Isamil, A. A. \& Salem, M. M. 1996. Production and characterization of bacterial coagulants as calf rennet replace for Egyptian cheese making. Egyptian Journal of Food Science, 24 (3), 417-449.

[23] Gupta, R.; Beg, q. K.; Lorenz, p. Bacterial alkaline proteases: molecular approaches and industrial applications. Applied Microbiology and Biotechnology, v. 59, p. 15-32, 2002. PMid: 12073127.

[24] Tripathi, P.; Tomar, R.; Jagannadham, M. V. Purification and biochemical characterization of a novel protease streblin. Food Chemistry, v. 125, p. 1005-1012, 2011.

[25] Devaraj, k. B.; Gowda, 1. R.; Prakash, v. An unusual thermostable aspartic protease from the latex of Ficus racemosa (L.). Phytochemistry, v. 69, p. 647-655, 2008.

[26] Demir, Y.; Güngör, A.; Duran, E.D.; Demir, 2008 N. Cysteine protease (capparin) from capsules of caper (Capparis spinosa). Food Technol. Biotechnol., 46, 286-291.

[27] Harboe, M. K.; Budtz, P. The production, action and application of rennet and coagulants. Technology of Cheese making. Sheffield Academic Press, 1999. p. 33-65.

[28] Roa I, López MB, Mendiola FJ. 1999. Residual clotting activity and ripening properties of vegetable rennet from Cynara cardunculus in La Serena cheese. Food Res Int 32:413-419. 